\title{
ALUMINUM NANOPARTICLES BURNING - STILL A PUZZLE?
}

\section{A. A. Gromov and E. M. Popenko}

The experimental data on the aluminum nanopowders ( $\mathrm{nAl}$ ) combustion in oxidizing media (air, propellants $\mathrm{AP}^{*} / \mathrm{HTPB}^{\dagger} / \mathrm{Al} / \mathrm{HMX}^{\ddagger}$, and energetic compositions) assuming the phenomenon of nitrides formation with the high yield is generalized. In the present work, the $\mathrm{nAl}$ produced by electrical explosion of wires was studied. The temperature, burning rate, and radiation were measured at combustion and the actual burning process was recorded by a videocamera. Scanning electron microscopy (SEM), X-ray diffraction (XRD), and chemical analysis were performed on the both initial powders and final condensed products. It was experimentally proved that the combustion process of aluminum nanoparticles was two staged independently of burning conditions in nitrogen-containing media. The formation of nitrides in presence of molecular nitrogen is the determining stage in the particles combustion. A qualitative discussion is given on the kinetic limitation for AlN (AlON) oxidation due to rapid condensation and encapsulation of solid AlN (AlON).

\section{INTRODUCTION}

Aluminum powders are widely used as boosters for propellants and energetic systems of various types $[1,2]$. That is why interest in the combustion mechanism of aluminum powders continues to grow and is still puzzling [3]. Although many researchers have reported the characteristics of the combustion process for micron-sized aluminum particles in numerous oxidizers (burning rate, combustion temperatures, brightness at each stage) $[4,5]$, consistent data have yet to be obtained [6]. The combustion of metal particles is a two or more stage process with the formation and decomposition of tens of products in different oxidizing media [1]. Traces of AlN in the final products of combustion were first reported in [7]. Boborykin et al. have proposed a theoret-

\footnotetext{
*AP - ammonium perchlorate.

${ }^{\dagger}$ HTPB - hydroxyl-terminated polybutadiene.

${ }^{\ddagger}$ HMX - cyclotrimethylene tetranitramine.
} 
ical explanation for the formation of $\mathrm{AlN}$ and its subsequent oxidation during combustion of $\mathrm{Al}$ in air [8]. Until recently, the role of nitrogen in the combustion of $\mathrm{Al}$ was shown to be insignificant [9-11]. However, in the work reported, a noticeable role of nitrogen in the combustion of $\mathrm{nAl}$ in air and in propellants was found. Nitride formation significantly decreased the burning enthalpy of the propellant. Recently, the $\mathrm{nAl}$ powder $\left(a_{\mathrm{BET}} \sim 100 \mathrm{~nm}\right)$ has drawn much interest as a component of propellant [12]. The use of $\mathrm{nAl}$ instead of industrial Al powders $\left(a_{\mathrm{BET}} \sim 10 \mu \mathrm{m}\right)$ resulted in the achievement of a doubled burning rate for aluminized solid propellant [13]. The complete substitution of industrial $\mathrm{Al}$ powders by $\mathrm{nAl}$ lead to an increase in the burning rate of combustion for aluminized solid propellant based on active binder (20\%), AP (27\%), HMX (35\%), and Al (18\%) [14]. The value of the pressure exponent $n$ was reduced in the burning law $u=A p^{n}$; at the same time, the combustion efficiency of metal was increased and the degree of agglomeration was reduced [15].

\section{EXPERIMENT AND DISCUSSION}

The physical and chemical properties of the $\mathrm{nAl}$ differ from those of micron-sized powders mainly due to their lower bulk density $\left(\sim 0.1 \mathrm{~g} / \mathrm{cm}^{3}\right)$, gas absorption $(3-$ $5 \%$ (wt.)), very thin oxide films on the particle surface, and capillary system [16]. The nAl obtained by the wire electrical explosion (WEE) method [17] is not pyrophoric after slow air-passivation, but can burn in the self-propagating regime in air by local ignition, which makes it different from micron-sized powders [18]. The combustion process of $\mathrm{nAl}$ was studied in two oxidizing media (air and propellant $\mathrm{AP} / \mathrm{HTPB} / 25 \% \mathrm{Al}(\mathrm{ASD}-4+\mathrm{nAl}) / \mathrm{HMX})$ in this work. A possible mechanism for the formation of $\mathrm{AlN}(\mathrm{AlON})$ from liquid and gaseous intermediates is discussed.

The specific surface area, determined by the Brunauer-Emmett-Teller (BET) method was $\sim 10 \mathrm{~m}^{2} / \mathrm{g}$. The aluminum metal content was $92 \%$ (wt.). The technique for $\mathrm{nAl}$ passivation has been discussed in [19], where different types of passivation coatings were used. The compositions of the final solid combustion products were studied by XRD, chemical analyses using the Kjeldahl method (bound nitrogen content), and the volumetric method (aluminum metal content) [20]. A videocamera was used to record the combustion process in air. Temperatures were measured using a W/Re thermocouple. The thermocouple was placed in the center of the conic samples. An optical sensor was employed for measurements of radiation from burning powders. The experiments were carried out in an air atmosphere and the burning of propellant compositions was studied in the 2.3-liter close vessel in argon. 


\subsection{Aluminum Nanopowders Burning in Air}

The $\mathrm{nAl}$ powder was poured onto a steel plate. The shape of the poured powder sample was conic. For five statistically studied nAl samples of equal mass $(4 \mathrm{~g})$, the ignition temperature determined by pyrometer was $750 \pm 100 \div 820 \pm 100 \mathrm{~K}$. Local ignition was initiated by an electrically heated $\mathrm{Ni}-\mathrm{Cr}$ alloy wire, which was placed at the top of the cone-like sample. After the ignition, combustion occured as a nonstationary two-staged process - thermal explosion with the phase transition (Fig. 1). At the first stage, the combustion waves of relatively low brightness propagated through the surface of the sample from the ignition point (Fig. 1a). The maximal combustion temperature during the first stage did not exceed $1400 \pm 100 \mathrm{~K}$ (Fig. 1b), but temperature increase was not reflected on the temperature curve (Fig. 2) because the thermocouple was placed in the center of the conic sample. After a rather slow first stage, fast temperature increase up to $2500 \pm 50 \div 2800 \pm 50 \mathrm{~K}$ (measured by thermocouple) was observed accompanied by bright radiation of white color (stage 2). The second stage (thermal explosion itself) usually began from the center of the sample and then propagated through the entire volume of the sample (Fig. 1c). After the second stage when the main part of $\mathrm{nAl}$ reacted, the sample rapidly cooled down.

X-ray diffraction and chemical analysis showed that the solid products of the first stage, which was quenched by argon, consisted of unreacted aluminum and amorphous aluminum oxides with some traces of AlN (bound nitrogen content $C_{\mathrm{N}}=0.5 \pm 0.3 \%$ (wt.), aluminum metal content $C_{\mathrm{Al}}=70.3 \pm 1.4 \%$ (wt.)). $\mathrm{X}$-ray diffraction patterns of the initial $\mathrm{nAl}$ and the quenched products of combustion after the first stage in air are similar: the most intense peaks belong to the $\mathrm{Al}$ phase. After the second stage of $\mathrm{nAl}$ combustion, the content of aluminum metal in the final combustion products substantially decreased

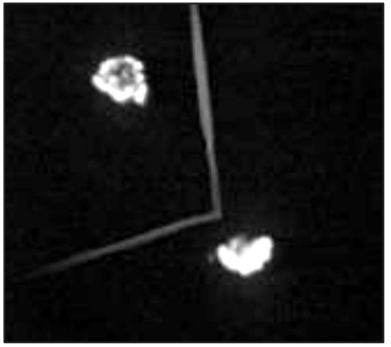

(a)

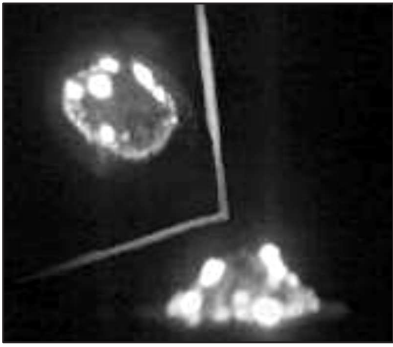

(b)

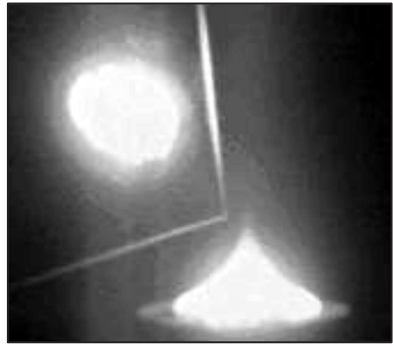

(c)

Figure 1 Video images and reflections of $\mathrm{nAl}(m=4 \mathrm{~g})$ burning in air: $(a)$ ignition; (b) 1st stage; and (c) 2nd stage 


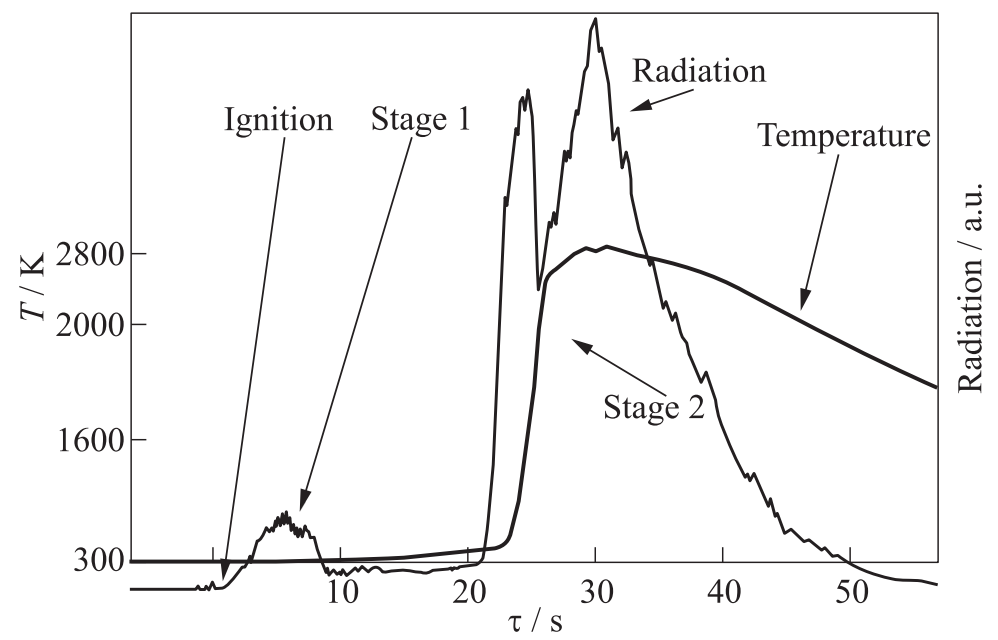

Figure 2 Radiation and temperature history of $\mathrm{nAl}$ powder $(m=4 \mathrm{~g})$ burning in air

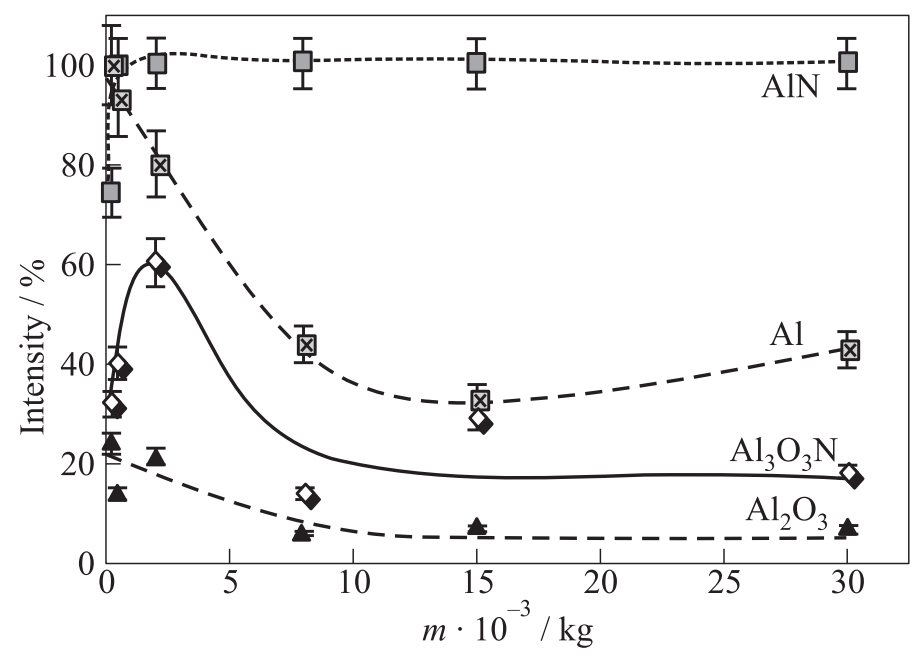

Figure 3 Phase composition of soild combustion products of $\mathrm{nAl}$ in air 


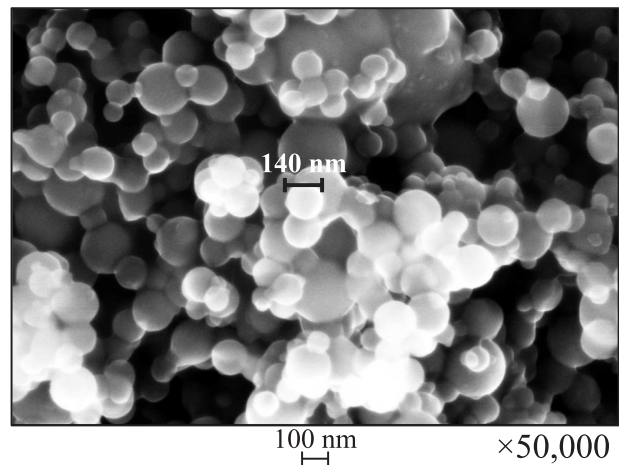

(a)

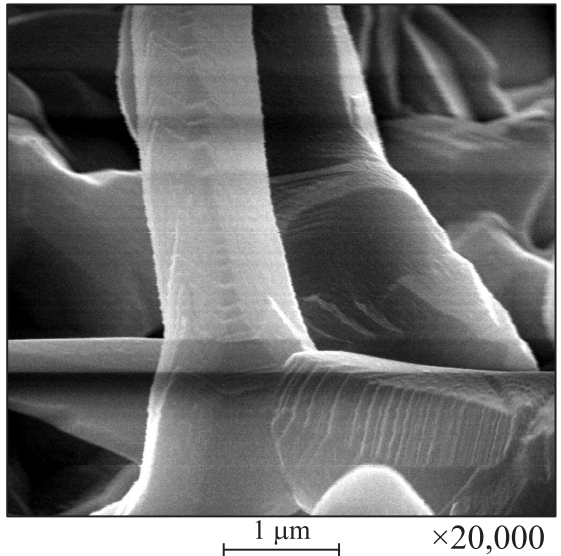

(b)

Figure 4 Scanning electron microscopy images of $\mathrm{nAl}(a)$ and its combustion products in air $(b)$

$\left(C_{\mathrm{Al}}=11.0 \pm 1.4 \%\right.$ (wt.) $)$ and the content of bound nitrogen increased $\left(C_{\mathrm{N}}\right.$ $=18.2 \pm 0.3 \%$ (wt.)). If all the nitrogen from air was assumed bound as AlN (Fig. 3), the content of AlN should be $C_{\mathrm{AlN}}=61.4 \%$ (wt.). Microstructures of $\mathrm{nAl}$ and the 2nd stage combustion products are shown in Fig. 4. The spherical particles of the initial nAl (Fig. 4a) completely changed their morphology during combustion: the final products consisted of needle-like polycrystals of micron and submicron size (Fig. 4b).

The phenomenon of the formation of a large amount of AlN ( 50\%(wt.)) by combustion of $\mathrm{nAl}$ layer in air was first observed in [21]. The authors of [21] showed that more than $50 \%$ (wt.) of AlN (AlON) formed in the course of combustion of a cone-like pile of ultrafine aluminum powder in air.

The main question in the mechanism of AlN formation in air is: Why does nitrogen from the air react with aluminum instead of the oxygen present? In the known AlN synthesis studies, if traces of oxygen appear, then AlN intensively reacted with oxygen to form $\mathrm{Al}_{2} \mathrm{O}_{3}$. The presence of high AlN phase concentration in the final products of $\mathrm{nAl}$ combustion contradicts with the formal thermodynamic calculations (the nitride must be further oxidized in air). During some period of time, the accumulation of AlN might be assumed due to the chemical binding of nitrogen only. In this case, AlN stabilization (more than $50 \%$ (wt.)) at high temperatures occurs only under the encapsulation of the nitride: otherwise, suboxidation of nitrides would occur. At low temperatures (first stage, $T<1400 \mathrm{~K}$ ), the oxidation process proceeds due to the diffusion of the oxidizers through the layer of products. Such behavior at metal combustion in gaseous oxi- 


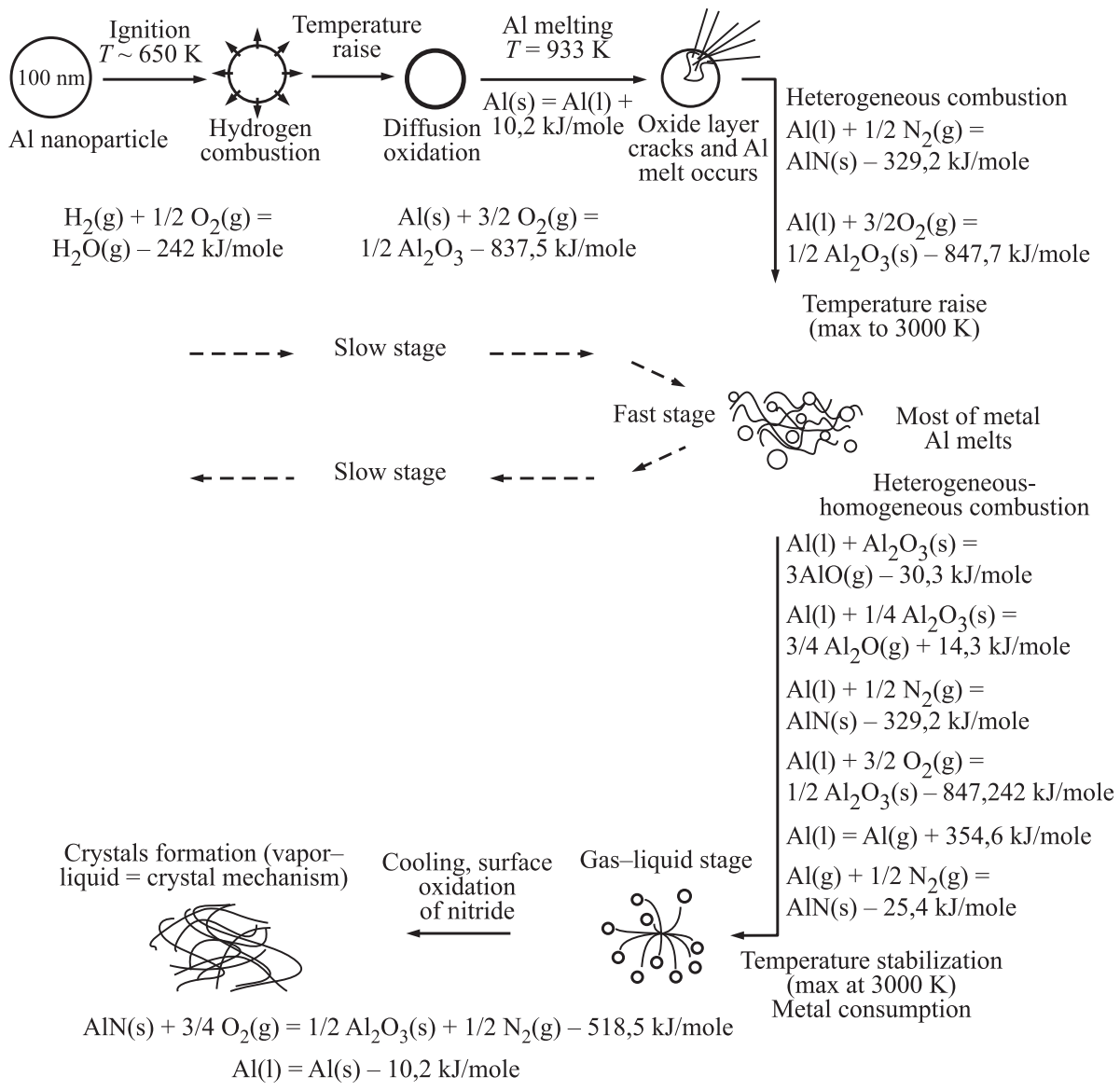

Figure 5 Thermodynamic model of nAl burning in air

dizers is well known for self-propagating high-temperature synthesis [22]. The combustion occurs in the "layer-by-layer" regime. The temperature gradients and the diffusion coefficients for such processes were described elsewhere [22]. According to XRD analysis (see Fig. 3), after the first stage of combustion of $\mathrm{nAl}$ in air, the main phase is unreacted aluminum.

According to the chemical analyses, the quenched product of the first combustion stage contains $C_{\mathrm{N}}=0.5 \pm 0.3 \%$ (wt.) and $C_{\mathrm{Al}}=70 \pm 1.4 \%$ (wt.). On the one hand, it means that $\sim 30 \%$ (wt.) belongs to amorphous $\mathrm{Al}_{2} \mathrm{O}_{3}$. On the other hand, the burning temperature of the samples is lower than $1400 \mathrm{~K}$. Additionally, the volatility of $\mathrm{Al}_{2} \mathrm{O}_{3}$ increases by a factor 2 due to the presence of molten aluminum. Theoretically, one can assume the probable reaction schemes 
during $\mathrm{nAl}$ combustion in air (Fig. 5). The formation and stabilization of nitrides during combustion of powdery elements in air is a normal feature not only for aluminum (present paper) and boron but also for zirconium. It was recently discovered that during the oxidation of powdered lanthanum in air, the final products contained $50 \%$ (wt.) of LaN [23].

\subsection{Aluminum Nanopowder Burning in the Four-Component Propellant}

Combustion of $\mathrm{AP} / \mathrm{HTPB} / \mathrm{Al} / \mathrm{HMX}$ propellant samples was conducted in an argon atmosphere in a constant-pressure device. The samples were fixed upright and ignited from the top with black powder. The pressure and the flame glow intensity were recorded automatically during combustion. The burning time of the samples was determined using pressure-time dependences. The pressure increased during the experiment (on the average by $0.1 \mathrm{MPa}$ ), and the burning rate was therefore normalized by the average pressure value. For the coefficients $A$ and $n$ in the burning rate law $u=A p^{n}$ of the energetic condensed system, the relative measurement error was $\pm 4.9 \%$ and $\pm 5.2 \%$, respectively, at a confidence probability of 0.95 . The combustion characteristics in the pressure range of 4.0-20.0 $\mathrm{MPa}$ are presented in Table 1.

The effect of $\mathrm{nAl}$ additives on the sample burning rate was evaluated using the dimensionless coefficient $K=u / u_{0}$ at pressures of 4.0 and $20.0 \mathrm{MPa}$ where $u$ is the burning rate of the samples with $\mathrm{nAl}$, and $u_{0}$ is the burning rate of the samples without nAl. As follows from Table 1, if ASD-4 is partially replaced by $\mathrm{nAl}$, the burning rate increases in accordance with the increase in the $\mathrm{nAl}$

Table 1 Effectiveness of exponent $n$ regulation in the combustion law of the model propellant by $\mathrm{nAl}$

\begin{tabular}{|c|c|c|c|c|}
\hline \multirow[t]{2}{*}{ № } & \multirow{2}{*}{$\begin{array}{c}\text { Content (type) of } \mathrm{nAl} \\
\text { in the composition of propellant, } \\
\% \text { (wt.) }\end{array}$} & \multicolumn{2}{|c|}{$K=u / u_{0}$ at pressure } & \multirow[t]{2}{*}{ Burning law } \\
\hline & & $4.0 \mathrm{MPa}$ & $20.0 \mathrm{MPa}$ & \\
\hline 1 & 0 (i.e., $100 \%$ of ASD-4) & 1.0 & 1.0 & $u=3.3^{0.50}$ \\
\hline 2 & $1.25\left(\mathrm{nAl}-\mathrm{Al}_{2} \mathrm{O}_{3}\right)^{*}$ & 1.2 & 1.0 & $u=4.5^{0.39}$ \\
\hline 3 & $5.0\left(\mathrm{nAl}-\mathrm{Al}_{2} \mathrm{O}_{3}\right)$ & 3.6 & 2.3 & $u=16.8^{0.23}$ \\
\hline 4 & $2.5\left(\mathrm{nAl}-\mathrm{AlB}_{2}\right)^{\dagger}$ & 1.1 & 1.0 & $u=3.7^{0.44}$ \\
\hline 5 & $5.0\left(\mathrm{nAl}-\mathrm{AlB}_{2}\right)$ & 3.4 & 2.1 & $u=16.8^{0.20}$ \\
\hline 6 & $2.5(\mathrm{nAl}-\mathrm{NC})^{\ddagger}$ & 2.9 & 1.8 & $u=14.3^{0.20}$ \\
\hline
\end{tabular}

*Aluminum nanopowder, passivated by air (Table 2).

${ }^{\dagger}$ Aluminum nanopowder, passivated by aluminum diboride (Table 2).

${ }^{\ddagger}$ Aluminum nanopowder, passivated by nitrocellulose (Table 2). 
Table 2 Properties of aluminum powders

\begin{tabular}{|c|c|c|c|c|c|c|c|}
\hline № & $\begin{array}{l}\text { Sample } \\
\text { code }\end{array}$ & $\begin{array}{c}\text { Initial } \\
\text { wire } \\
\text { composition }\end{array}$ & $\begin{array}{c}\text { Gas media } \\
\text { in explosive } \\
\text { chamber }\end{array}$ & $\begin{array}{l}\text { Passivation } \\
\text { condition }\end{array}$ & $\begin{array}{l}\mathrm{BET}, \\
\mathrm{m}^{2} / \mathrm{g}\end{array}$ & $\begin{array}{c}a_{\mathrm{BET}} \\
\mu \mathrm{m}\end{array}$ & $\begin{array}{l}C_{\text {metal }}, \\
\% \text { (wt.) }\end{array}$ \\
\hline 1 & $\mathrm{nAl}-\mathrm{Al}_{2} \mathrm{O}_{3}$ & $\mathrm{Al}$ & $\mathrm{Ar}$ & Air & 7.0 & 0.3 & 76.1 \\
\hline 2 & $\mathrm{nAl}-\mathrm{AlB}_{2}$ & $\mathrm{Al}(\mathrm{B})$ & Ar & Air & 17.0 & 0.1 & 78.2 \\
\hline 3 & $\mathrm{nAl}-\mathrm{NC}$ & $\mathrm{Al}$ & Ar & $\begin{array}{l}\text { Nitrocellulose } \\
\text { in ethanol }\end{array}$ & 5.0 & 0.4 & 67.5 \\
\hline 4 & ASD-4 & \multicolumn{3}{|c|}{ Industrial powder } & 0.4 & 5.6 & 98.5 \\
\hline
\end{tabular}

content. At $\mathrm{nAl}$ contents of $1.25 \%$ and $5.0 \%$, the burning rate at a pressure of 4.0 $\mathrm{MPa}$ increased by a factor of 1.2 and 3.6. The exponent $n$ decreased from 0.5 (the sample without $\mathrm{nAl}$ ) to 0.39 and 0.23 .

The increase in the burning rate of the energetic condensed system due to the partial replacement of ASD-4 by $\mathrm{nAl}$ is apparently explained by the smaller combustion time of $\mathrm{nAl}$ particles. One more factor responsible for the increase in the burning rate upon the addition of $\mathrm{nAl}$ is a decrease in the degree of particle agglomeration in the combustion wave with increasing aluminum particle size. It has been shown previously that the larger the aluminum particle size, the smaller the volume-averaged size of the agglomerates formed. The surface area of the agglomerated particles remains large enough, so that their higher burning rate is higher than the burning rate of large particles of ASD-4 even under the agglomeration conditions of the $\mathrm{nAl}$ combustion products. The decrease in the exponent $n$ due to the addition of $\mathrm{nAl}$ can be related to the effect of $\mathrm{nAl}$ on the heat release in the condensed-phase reaction layer. The thermal contribution from aluminum oxidation in the condensed-phase reaction layer increases as the aluminum powder content increases. The fraction of the heat released in the condensed phase as a result of aluminum oxidation $(d=20-60 \mu \mathrm{m})$ is $\approx 25 \%$ of the total amount of heat released in the condensed phase.

Because the reactivity of $\mathrm{nAl}$ is higher than that of $\mathrm{ASD}-4$, one might expect a higher temperature in the $\mathrm{nAl}$ oxidation zone and an enlargement of the heating zone in the condensed phase. The temperature increase and the enlargement of the heating zone apparently result in reducing the role of processes occurring in the aerosol zone and in decreasing the coefficient $n$ for the $\mathrm{nAl}$-containing compositions. A considerable increase in the particle size of the $\mathrm{nAl}-\mathrm{AlB}_{2}$ sample did not lead to an increase in the burning rate of the model energetic condensed system compared to the composition containing $\mathrm{nAl}-\mathrm{Al}_{2} \mathrm{O}_{3}$ (see Table 1). Probably, during mixing of $\mathrm{nAl}$ and rubber, $\mathrm{nAl}-\mathrm{Al}_{2} \mathrm{O}_{3}$ particle agglomerates disintegrated and the stronger agglomerates in the system containing $\mathrm{nAl}-\mathrm{AlB}_{2}$ sintered in the heating zone with particle size reduction. 
The addition of $2.5 \% \mathrm{nAl}-\mathrm{NC}$ to the system resulted in the same increase in the burning rate and the same decrease in the exponent $n$ as with the addition of $5 \% \mathrm{nAl}-\mathrm{Al}_{2} \mathrm{O}_{3}$. In the $\mathrm{nAl}-\mathrm{NC}$ sample, the mass concentration of $\mathrm{NC}$ was $33 \%$; therefore, on propellant basis, the $\mathrm{nAl}$ content was $1.7 \%$ and the $\mathrm{NC}$ content was $0.8 \%$. Nitrocellulose has a low temperature of the beginning of intense decomposition $\left(160{ }^{\circ} \mathrm{C}\right)$; therefore, there is a high probability that $\mathrm{NC}$ undergoes exothermic decomposition in the condensed-phase reaction layer. Because of the low NC content in the propellant, the heat release due to thermal decomposition of $\mathrm{NC}$ is insignificant and cannot have an appreciable effect on the heat balance of the condensed phase since NC reacts weakly with nAl. Apparently, the reason for the effectiveness of $\mathrm{NC}$ as a modifying agent of combustion is its interaction with the other propellant components, in particular, with AP.

\subsection{Mathematical Modeling of the Aluminum Nanopowder Oxidation in Nonisothermal Condition}

The mathematical modeling of the processes of $\mathrm{nAl}$ ignition in air-as-oxidizer was executed by using the equations of heat balance:

$$
c \rho \frac{d T}{d \tau}=-\sigma \frac{d S}{d \tau}+\lambda \Delta T
$$

where $c$ is the specific heat; $\rho$ is the density; $T$ is the temperature; $\tau$ is the time; $\lambda$ is the thermal conductivity; $\sigma$ is the specific surface energy; $S$ is the free surface of the unit powder volume:

$$
S(\tau)=S_{\mathrm{sp}}-\left(\frac{\rho}{\rho_{0}} \frac{3}{4 \pi r^{3}}\right) z s(\tau)
$$

$S_{\mathrm{sp}}$ is the initial specific surface; $r$ is the mean-surface particle radius; $z$ is the coefficient; and $s(\tau)$ is the contact surface of particles; assuming a lowdimensional object, one obtains:

$$
\sigma=\frac{Q}{\Delta S_{\mathrm{sp}}}
$$

where $Q$ is the heat of oxidation; and $\Delta S_{\mathrm{sp}}$ is the change in the surface energy by oxidation (for nAl, $Q=5-6 \mathrm{~kJ} / \mathrm{g}$ and $\Delta S_{\mathrm{sp}} \sim 1 \mathrm{~m}^{2} / \mathrm{g}$; therefore, $\sigma=0.5-$ $\left.0.6 \mathrm{~kJ} / \mathrm{m}^{2}\right)$.

The kinetic equation is taken in the form:

$$
\frac{d \alpha}{d \tau}=k \exp \left(\frac{E_{a}}{R T}\right) \alpha^{-n} \exp \left(-k_{1} \alpha\right), \mathrm{s}^{-1} .
$$




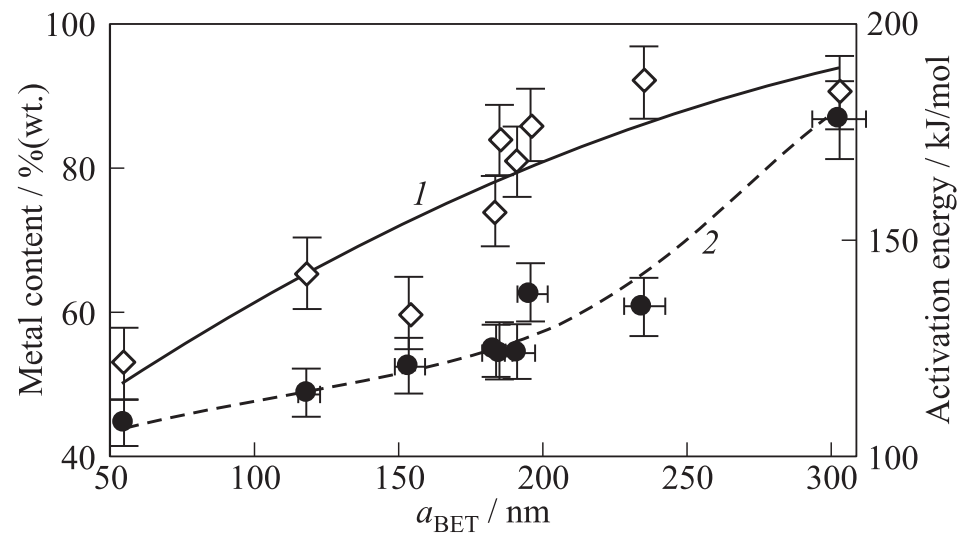

Figure 6 Experimental metal content of $\mathrm{nAl}(1)$ and activation energy of $\mathrm{nAl}$ oxidation (2) vs. $a_{\mathrm{BET}}$

The oxidation onset temperature $T_{c}, \mathrm{~K}$, was determined assuming equilibrium of heat fluxes (from the sample and into the sample) by

$$
T_{c}=-\frac{E_{a}}{R \ln (\nu c / Q k)}
$$

where $E_{a}$ is the activation energy; $\nu$ is the rate of sample heating; $R$ is the universal gas constant; $\alpha$ is the degree of transformation; and $d \alpha / d \tau$ is the rate of the oxidation reaction.

The experimentally observed regime of heat explosion by $\mathrm{nAl}$ burning (see Fig. 1) allows one to estimate the activation energy for $\mathrm{nAl}$ entering Eq. (1).

Calculation of the self-ignition activation energy (Fig. 6) was made for the initial (linear) period of oxidation, in which the heat equilibrium broke up. The activation energy of oxidation and experimentally determined metal content in $\mathrm{nAl}$ increased with $a_{\mathrm{BET}}$.

The calculated temperatures of oxidation onset agreed well with the calculated values in the range of $670-730 \mathrm{~K}$ (Fig. 7).

It was experimentally proved that the combustion process of aluminum nanoparticles was one or two staged independently of the burning condition in nitrogen-containing media. The formation of nitrides in the presence of molecular nitrides is the determining stage of particle combustion (Fig. 8). Instead of aluminum oxide, the composition of combustion products for $\mathrm{nAl}$-containing propellant is represented by $\mathrm{AlN}$ and $\mathrm{Al}_{3} \mathrm{O}_{3} \mathrm{~N}$ with $\mathrm{Al}_{2} \mathrm{OC}$. 


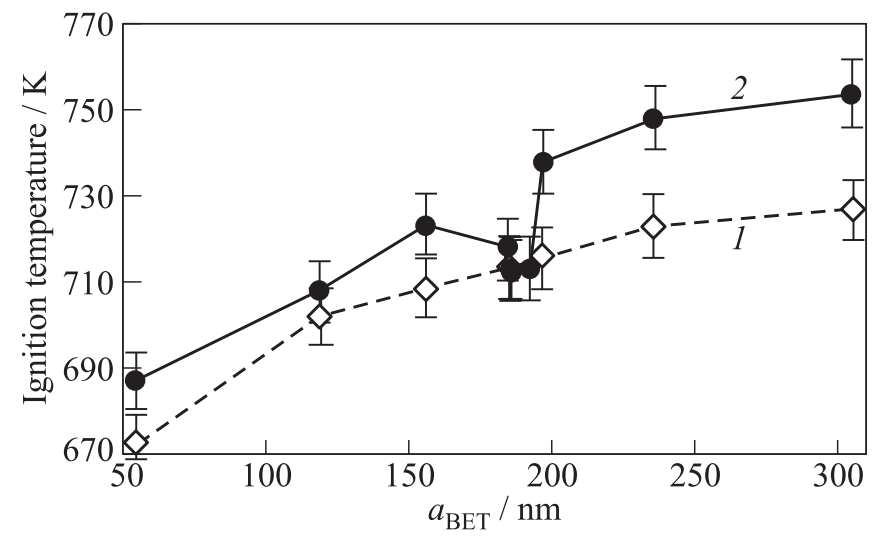

Figure 7 Simulation (1) and experimental (2) temperatures of the oxidation onset for $\mathrm{Al}$ particles

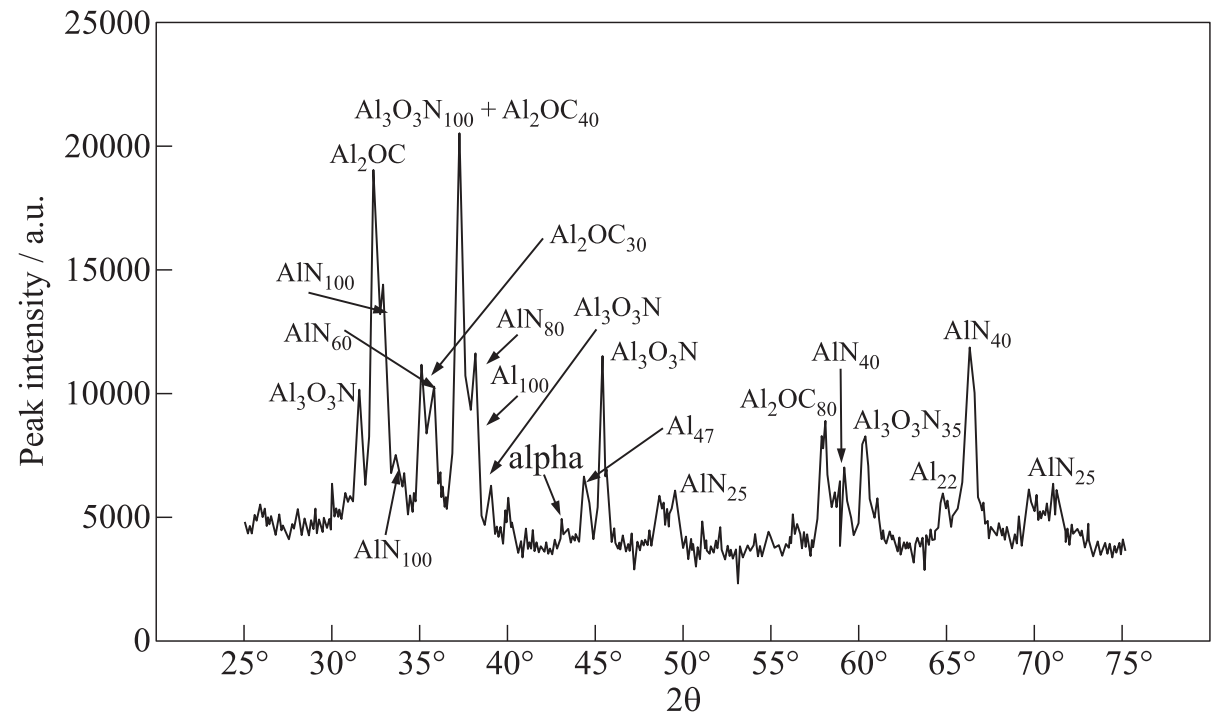

Figure 8 X-ray diffraction pattern of the combustion products of the model aluminized composition AP/HMX/HTPB/25\% nAl 


\section{CONCLUDING REMARKS}

The effects of $\mathrm{nAl}$ burning in oxidizing media were studied. It has been found that

(1) large amount of nitrogen-containing needle-shaped products was formed in the neat powderes burned in air (nitrides and oxynitrides); and

(2) the burning characteristics of propellants could be controlled by adding small amounts of $\mathrm{nAl}$ to industrial $\mathrm{Al}$ powders.

Both effects manifest themselves at the same time - even small $\mathrm{nAl}$ additives could improve propellant burning characteristics but the burning enthalpy of such a propellant could be lower because of the lower enthalpy (by a factor of 2.5) of the reaction:

$$
\mathrm{Al}+\frac{1}{2} \mathrm{~N}_{2}=\mathrm{AlN}-319 \mathrm{~kJ}
$$

instead of reaction

$$
\mathrm{Al}+\frac{3}{4} \mathrm{O}_{2}=\frac{1}{2} \mathrm{Al}_{2} \mathrm{O}_{3}-837.5 \mathrm{~kJ}
$$

\section{ACKNOWLEDGMENTS}

This work was supported financially by the International Grant "Global Energy" 2006 and Russian Federation President Grant MK 777.2007.2 and performed under the contract with the International Science and Technology Center (ISTC), Moscow.

\section{REFERENCES}

1. Pokhil, P.F., A.F. Belyaev, Yu. V. Frolov, V.S. Logachev, and A.I. Korotkov. 1972. Combustion of powdered metals in active media. Moscow: Nauka. (See also FTD-MT-24-551-73 translate from Russian by Foreign Technology Division. Wright Patterson Air Force Base. Ohio. Oct. 1973.)

2. Kuo, K. K., and M. Summerfield, eds. 1984. Fundamentals of solid propellant combustion. New York: AIAA.

3. Dreizin, E. L. 1999. On the mechanism of asymmetric aluminum particle combustion. Combust. Flame 117(4):841-50. 
4. Ji, Z., and L. Shufen. 1999. Aluminum oxidation in nitramine propellant. Propellants Explosives Pyrotechnics 24(4):224-26.

5. Servaites, J., H. Krier, J. C. Melcher, and R. L. Burton. 2001. Ignition and combustion of aluminum particles in shocked $\mathrm{H}_{2} \mathrm{O} / \mathrm{O}_{2} / \mathrm{Ar}$ and $\mathrm{CO}_{2} / \mathrm{O}_{2} / \mathrm{Ar}$ mixtures. Combust. Flame 125(1-2):1040-54.

6. Zhu, Y., and S. Yuasa. 1998. Effects of oxygen concentration on combustion of aluminum in oxygen/nitrogen mixture streams. Combust. Flame 115(3):327-34.

7. Gremyachkin, V. M., A. G. Istratov, and O. I. Leipunskii. 1975. Model for the combustion of metal droplets. Combust. Explosion Shock Waves 11(3):313-18.

8. Boborykin, V. M., V. M. Gremyachkin, A. G. Istratov, V.I. Kolesnikov-Svinaryov, G.P. Kuznetsov, O. I. Leypunskii, and V. M. Puchkov. 1983. Effects of nitrogen on the combustion of aluminum. Combust. Explosion Shock Waves 19(3):270-76.

9. Dreizin, E. L. 1996. Experimental study of stages in aluminium particle combustion in air. Combust. Flame 105(4):541-56.

10. Yuasa, S., Y. Zhu, and S. Sogo. 1997. Ignition and combustion of aluminum in oxygen/nitrogen mixture streams. Combust. Flame 108(4):387-90.

11. Swihart, M. T., and L. Catoire. 2000. Thermochemistry of aluminum species for combustion modeling from Ab Initio molecular orbital calculations. Combust. Flame 121(1-2):210-22.

12. Teipel, U., and I. Mikonsaari. 2002. Size reduction of particulate energetic material. Propellants Explosives Pyrotechnics 27(3):168-74.

13. Ivanov, Yu.F., M. N. Osmonoliev, V.S. Sedoi, V. A. Arkhipov, S. S. Bondarchuk, A. B. Vorozhtsov, A. G. Korotkikh, and V.T. Kuznetsov. 2003. Productions of ultra-fine powders and their use in high energetic compositions. Propellants Explosives Pyrotechnics 28(6):319-33.

14. Simonenko, V. N., and V.E. Zarko. 1999. Comparative studying of the combustion behavior of composite propellants containing ultra fine aluminum. In: Energetic Materials. 30th Annual Conference (International) of ICT. Karlsruhe, Germany. Report 21.

15. Glotov, O. G., V. E. Zarko, and M. W. Beckstead. 2000. Agglomerate and oxide particles generated in combustion of Alex containing solid propellants. In: Energetic Materials. Analysis, Diagnostics and Testing. 31th Annual Conference (International) of ICT. Karlsruhe, Germany. Report 130.

16. Il'in, A.P., and A. A. Gromov. 1999. Oxidation of aluminum and boron superfine powders. Tomsk: Tomsk Polytechnic University. (In Russian.)

17. Kwon, Y.-S., Y.-H. Jung, N. A. Yavorovsky, A. P. Ilyin, and J.-S. Kim. 2001. Ultrafine powder by wire explosion method. Scripta Mater. 44(8-9):2247-51.

18. Kwon, Y.-S., A. A. Gromov, and A. P. Ilyin. 2002. Reactivity of superfine aluminum powders stabilized by aluminum diboride. Combust. Flame 131(3):349-52.

19. Kwon, Y.-S., A. A. Gromov, A.P. Ilyin, and G.-H. Rim. 2003. Passivation process for superfine aluminum powders obtained by electrical explosion of wires. Appl. Surf. Sci. 211(1-4):57-67.

20. Fedotova, T.D., O. G. Glotov, and V.E. Zarko. 2000. Chemical analysis of aluminum as a propellant ingredient and determination of aluminum and aluminum 
nitride in condensed combustion products. Propellants Explosives Pyrotechnics 25(6):325-32.

21. Il'in, A.P., and L. T. Proskurovskaya. 1990. Two-stage combustion of an ultradispersed aluminum powder in air. Combustion Explosion Shock Waves 26(2):190-92.

22. Merzhanov, A. G. 1996. Combustion processes that synthesize materials. J. Mater. Process. Technol. 56(1-4):222-41.

23. Shevchenko, V. G., V. I. Kononenko, N. V. Lukin, I. N. Latosh, and I. A. Chupova. 1999. Effect of conditions under which powdered lanthanum is heated on its interaction with air. Combust. Explosion Shock Waves 35(1):77-79. 